\title{
ПРАКТИЧНА ПІДГОТОВКА СТУДЕНТІВ ДО ПСИХОЛОГІЧНОЇ РОБОТИ 3 ДІТЬМИ-ІНВАЛІДАМИ
}

Стаття присвячена аналізу формування особистісної та професійної готовності студентів спеиіальності 053 «Психологія» до майбутньої психологічної роботи з дітьми-інвалідами $в$ реабілітаційних центрах та психологічного супроводу дітей в класах з інклюзивною освітою. Зазначено, щзо сформувати практичні вміння та навички є можливим лише за умови безпосередньої взаємодії та спілкування з останніми, що у Міжнародному економіко-гуманітарному університеті імені академіка Степана Дем'янчука стає можливим завдяки реалізації проекту "На хвилях посмішок», який трунтується на сочіальному партнерстві та має на меті залучення студентів у широке коло соиіальних взаємозв'зків, розширення соиіокультурного досвіду, формування толерантності як якості особистості, що являе собою інтегративну сукупність пізнавального,

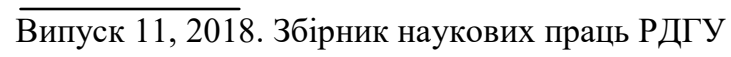


емоційного та поведінкового компонентів та є готовністю до конструктивного діалогу на основі поваги, емпатії, прийняття. Автор зазначає ичілі, завдання, структуру, принципи реалізації та напрямки проекту, описує прогнозовані результати змін для студентів-психологів. Представлено аналіз результатів опитування студентів денної форми навчання.

Ключові слова: дитина-інвалід, суб'єкт-суб'єктна взаємодія, професійно-особистісний розвиток, професійна діяльність, гуманізм, толерантність, психотравма, психотренінгові технології.

Статья посвящена анализу формирования личностной и профессиональной готовности студентов специальности 053 «Психология» $\kappa$ будущей психологической работе с детьмиинвалидами в реабилитащионных иентрах и к психологическому сопровождению детей в классах $c$ инклюзивным образованием. Отмечено, что сформировать практические умения и навыки возможно только при условии непосредственного взаимодействия и общения с детьми-инвалидами, что в Международном экономико-гуманитарном университете имени академика Степана Демьянчука становится возможным благодаря реализачии проекта «На волнах ульббок», основанном на сочиальном партнерстве и имеющем иелью привлечение студентов в широкий круг социальных взаимосвязей, расширение социокультурного опыта, формирование толерантности как качества личности, что представляет собой интегративную совокупность познавательного, эмоционального $u$ поведенческого компонентов и является готовностью к конструктивному диалогу на основе уважения, эмпатии, принятия. Автор отмечает иели, задачи, структуру, принципь реализации и направления проекта, описывает прогнозируемые результаты изменений для студентов-психологов. Представлен анализ результатов опроса студентов дневной формы обучения.

Ключевые слова: ребенок-инвалид, субъект-субъектное взаимодействие, профессиональноличностное развитие, профессиональная деятельность, гуманизм, толерантность, психотравма, психотренинговые технологии.

Постановка проблеми. «Світовою тенденцією сучасності, - як слушно вказують А.А. Колупаєва та Л.О. Савчук, - $\epsilon$ прагнення деінституалізації та соціальної адаптації осіб 3 особливостями психофізичного розвитку» [2, с. 26.]. Останнє передбачає якісну професійну практичну підготовку фахівців: педагогів та психологів.

Аналіз останніх досліджень i публікацій. Питанням вивчення взаємозв'язку теорії із практикою у професійній підготовці психологів займалися Г. Балл, Е. Зеєр, Л. Карамушка, В. Панок, Ю. Приходько, Т. Титаренко, С. Максименко, А. Маркова, К. Роджерс, Ю. Швалб та інші.

Формулювання цілей статті. Метою публікації є висвітлення теоретико-практичних основ професійної підготовки психологів завдяки реалізації Проекту «На хвилях посмішок».

Виклад основного матеріалу дослідження. Психологічна готовність до супроводу дитини 3 особливими потребами в класах інклюзивної освіти та реабілітаційних центрах включає два блоки готовності: 1) особистісну; 2) професійну.

Особистісна готовність передбачає високий рівень сформованості мотиваційно-ціннісного компонента до психологічної роботи 3 особами 3 особливими потребами та набір особистісних якостей, що дозволять майбутньому психологу ефективно здійснювати свою роботу. Особистісна готовність передбачає наявність розвиненого емоційно-вольового компоненту, до якого належить емоційна стійкість, що є складовою особистісної зрілості, адже психолог має бути готовим до важких емоційних переживань в процесі роботи $з$ дітьми-інвалідами та їх батьками, бути аутентичним пред’являти щирі емоції та почуття.

Професійна готовність передбачає знання, уміння та навички до психологічного супроводу людей 3 особливими потребами. Студент-психолог повинен оволодіти нормативними психологічними дисциплінами, дисциплінами професійної кваліфікації, психологічними основами соціалізації та адаптації дітей-інвалідів, основами соціально-психологічної реабілітації, знаннями професійної етики. Становлення особистості психолога як суб'єкта професійної діяльності відбувається під час навчання у закладі освіти на основі принципу гуманізму, за яким особистість $€$ найважливішою цінністю.

Вважаємо, що сформувати практичні професійні уміння та навички для роботи 3 дітьмиінвалідами $\epsilon$ можливим лише за умови безпосередньої взаємодії та спілкування з останніми (власне, на це вказує Б.М. Теплов, говорячи про те, що навички не можуть виникнути поза відповідної предметної діяльності [6]). Особистісна готовність також не може бути сформована поза предметної діяльності з дітьми з особливими потребами, адже емоційна стійкість формується лише завдяки та під час процесу взаємодії та спілкування. 
Так, в процесі функціонально-рольових відносин з дітьми-інвалідами відбувається зміна в структурі особистісних смислів, коли гуманність, доброзичливість, толерантність, емпатія, готовність допомогти, співпереживання, повага інтеріоризуються та, в подальшому, визначають основу, на якій базуються особистісні відносини та спілкування психолога 3 дитиною-інвалідом та його батьками. Такий вид діяльності є діяльністю інтерактивного типу, ситуацією «разом» під час проживання різних типів взаємодій, коли $є$ можливість формування толерантного ставлення та прийняття особливих проявів дитини-інваліда (так званий «чинник різноманітності», що свідчить про визнання однакової цінності кожної дитини $[1$, с. 20]), уміння виявляти їх інтереси та потреби в різних видах діяльності та уміння взаємодіяти: робити вправи, виконувати завдання, підтримувати правила ігрового середовища $[7$, с. 26], уміння налагоджувати простір довіри та підтримки, якісно проводити розвивальні (тренінгові) та корекційні заняття з дітьми, що забезпечить їх успішну соціалізацію та групи зустрічей з батьками. Описаний простір взаємодії передбачає визнання цінності дитиниінваліда як особистості, що має право на вільний розвиток, різного роду самопрояви з безумовним толерантним ставленням до неї. Емоційно-вольовий компонент характеризує якості особистостіпсихолога, що забезпечать успіх та результативність процесу соціально-психологічного супроводу й соціально-психологічної реабілітації та включає: уміння зберігати внутрішню рівновагу, наявність поведінкової гнучкості при взаємодії із дитиною-інвалідом, вміння розпізнавати емоційні стани дитини.

Професійна готовність передбачає формування професійних умінь та навичок у процесі діагностування, консультування, розвивальної роботи та психологічної корекції, включаючи комунікативні та організаторські уміння. Міжнародним економіко-гуманітарним університетом імені академіка Степана Дем'янчука у 2017 році було започатковано Проект «На хвилях посмішок» (далі Проект), що має на меті фізичний та психологічний супровід дітей-інвалідів та психологічну допомогу батькам дітей з особливими потребами. В контексті вказаного Проекту перераховані уміння та навички студентів - майбутніх психологів реалізуються в процесі налагодження конструктивного контакту та безпосередньої взаємодії із дітьми-інвалідами та їх батьками.

3 метою дослідження ступеня готовності студентів спеціальності 053 «Психологія» до психологічного супроводу та психологічної допомоги дітям з особливими потребами нами було розроблено та проведено анкетування студентів денної форми навчання 1-4 курсів бакалаврату та 1-2 курсів магістратури Міжнародного економіко-гуманітарного університету імені академіка Степана Дем'янчука. Кількість опитаних 76 студентів віком 16-28 років. Метою опитування стало з'ясування готовності студентів - майбутніх психологів до психологічної допомоги дітям 3 особливими потребами та їх батькам на волонтерських засадах, тобто до проведення різного роду розвивальних (в даному випадку тренінгових) та консультаційних заходів.

Перше запитання анкети, власне, так і звучало: «Чи готові Ви допомагати дітям з особливими потребами та їх батькам на волонтерських засадах (проводити або допомагати психологу в організації та проведенні різного роду корекційних та розвивальних занять)? Якщо Ваша відповідь «ні», то вкажіть, будь-ласка, причину цьому».

Так, результати опитування показали, що найбільш мотивованими до психологічної допомоги дітям-інвалідам та їх батькам виявилися студенти 1-2 курсів (92\% та 94 \% відповідно). Починаючи із 3-го курсу спостерігається різке зниження готовності студентів працювати на волонтерських засадах, проте, показники залишаються достатньо високими - відповідно 73 \% та 61 \% в опитаних студентів 3-го та 4-го курсів. До причин неготовності студенти відносять: наявність роботи або ії пошук, бажання лише часткової зайнятості в якості волонтерів (1-2 рази на тиждень). Лише 1 студент 4-го курсу, даючи негативну відповідь, зазначив, що професія психолога - це не те, чим він планує займатися у майбутньому. $54 \%$ та 48 \% студентів магістратури відповіли позитивно на можливість бути волонтерами у Проекті «На хвилях посмішок».

Наступне запитання анкети для студентів: «Які особисті якості Ви можете розвинути завдяки роботі 3 дітьми 3 особливими потребами та їх батьками?» ми отримали наступні результати відповідей (наведемо найчастіше названі опитаними): толерантність (93\%), уміння чути (77\%), бажання допомогти (60\%), емпатія та співчуття (94\%), доброта (89 \%), відкритість (93\%), щирість (66 \%), неупередженість до думок та почуттів інших (86 \%), емоційна стійкість (92 \%), любов до життя (75\%), цінність власного здоров'я та життя (65\%), мужність (26 \%), доброзичливість (73\%), щедрість (23\%).

Останнє - третє запитання нашого опитування студентів стало: «Які особистісні якості Вам допоможуть при роботі з дітьми з особливими потребами та їх батьками?» Серед якостей, що виділені студентами були наступні (наведемо найчастіше названі опитаними): любов до дітей (92 \%), 
бажання допомогти (89\%), щирість (77 \%), відкритість (60 \%), наполегливість (93\%), емоційна стійкість (97\%), бажання професійного розвитку (55\%), толерантність (64 \%), чесність (71 \%).

Процесійно-діяльнісний етап було реалізовано засобами Проекта «На хвилях посмішок», що грунтується на соціальному партнерстві та має на меті залучення студентів спеціальності 053 «Психологія» у широке коло соціальних взаємозв'язків 3 метою розвитку конструктивного спілкування 3 дітьми $з$ особливими потребами, розширення соціокультурного досвіду, формування толерантності як якості особистості, що являє собою інтегративну сукупність пізнавального, емоційного та поведінкового компонентів та визначає активну ціннісну позицію у взаємодії з іншими не залежно від їх культурної, соціальної приналежності, віри, національності, віку, освіти, професії, гендеру, поглядів, стану здоров'я. Толерантність є готовністю до конструктивного діалогу 3 людиною, що викликає негативні емоційні реакції на основі поваги, прийняття, відкритості до взаємодії, уваги тощо. А, отже, зміст протиріччя та момент перетворення «негативу» в «позитив» й визначає специфіку толерантності. Включення студентів у практико-орієнтувальне середовище дозволяє формувати та удосконалювати професійні уміння та навички, розвивати особистісні якості та творчу індивідуальність, активізуючи процес професійно-особистісного розвитку та формуючи особистісну зрілість, адже передбачається, що участь у Проекті дасть можливість студентам осмислити проблеми дитини-інваліда.

Цілі Проекту мають три спрямування.

1. Для дітей 3 особливими потребами Проект передбачає формування простору психологічного комфорту та психологічної безпеки; прийняття та розуміння фізичних та психічних обмежень; зняття психоемоційного напруження засобами арт-терапії; навчання дитини слухати ведучого, бачити, чути, відчувати, дотримуватись черговості при виконанні вправ тощо [5, с. 8].

2. Для батьків дітей з особливими потребами передбачається: 1) підвищення когнітивної складності в питаннях дитячої психології, вікової та педагогічної психології, дефектології, патопсихології, клінічної психології, психології творчості та обдарованості, основ дитячої та підліткової психотерапії, основ психокорекції, психологічного супроводу людей з особливими потребами, психології здоров'я, психології сім’і, основ соціально-психологічної реабілітації, що $\epsilon$ кроком до залучення в просвітницьку діяльність; 2) афективна переоцінка психотравмуючої ситуації засобами зняття психоемоційного напруження засобами арт-терапії та психотренінгових технологій завдяки формуванню простору психологічної безпеки та прийняття; 3) налагодження соціальних контактів, що дасть можливість успішному існуванню в соціумі. Тому, очікувані результати повинні стосуватися трьох площин: когітивної, афективної та конативної.

3. Для студентів спеціальності 053 «Пихологія» Проект має на меті: вироблення практичних умінь (консультування, організації та проведенні психотренінгів, соціальнопсихологічної допомоги, підтримки, опіки) взаємодії з дітьми з особливими потребам; формування толерантності до них, навчання продуктивним комунікаціям, діалогічної взаємодії задля розуміння потреб та бажань людей з особливими потребами; вироблення навичок консультування батьків дітейінвалідів.

Програма має на меті розв'язання наступних завдань:

- поглибити теоретичні завдання та оволодіти практичними навичками студентами психологічного супроводу дітей з особливими потребами;

- формування у студентів гуманного ставлення до дітей-інвалідів;

- розвиток комплексу умінь та навичок, що забезпечитимуть подальшу роботу із соціальнопсихологічного супроводу;

- розвиток толерантності як цінності на особистісному рівні у студентів;

- оволодіння техніками конструктивного діалогу з людьми з особливими потребами;

- розвиток навичок толерантної поведінки студентів під час інтерактивної взаємодії (навчальної, розвивальної, тренінгової).

Основними принципами реалізації Проекта є: принцип гуманності; принцип толерантного середовища, що базується на безумовному прийнятті; принцип індивідуального підходу до кожної дитини з особливими потребами та її батьків; принцип рефлексивної позиції.

Реалізація Проекта в площині розвитку студентів здійснюється за наступними напрямками: підвищення когнітивної складності особистості студента (розвиток системи знань про багатогранність психологічних та соціальних проблем, передусім, проблем людей з особливими потребами);

- $\quad$ підвищення емоційної стійкості студента - майбутнього психолога, розвиток емпатії та толерантності останнього; 
- $\quad$ розвиток готовності студента-психолога до психологічної допомоги людям 3 обмеженими фізичними та психічними можливостями; розвиток навичок співпраці та налагодження конструктивного діалогу.

Прогнозовані результати змін для студентів-психологів:

- створення сприятливих просторових умов для професійної самореалізації особистості студента, що взаємодіятиме 3 оточуючим світом - дітьми та їх батьками, що потребують психологічної допомоги та підтримки;

- формування толерантної свідомості, що базується на гуманному ставленні в цілому до людей, i, передусім, людей з обмеженими можливостями та формування готовності до допомоги (в разі необхідності);

- формування позитивної «Я-концепції» майбутнього професіонала;

- покращення емоційно-психологічного стану студентів через реалізацію ними власного професійного потенціалу.

Структура програми включає:

- збагачення навчальної діяльності технологіями суб'єкт-суб'єктної взаємодії студентів: а) 3 дітьми 3 обмеженими можливостями 3 метою формування толерантного ставлення до фізичних та психічних обмежень та готовності до консультування, допомоги, психологічного супроводу, підтримки, опіки. Дана технологія реалізується засобами проведення спільних занять студентів 3 дисципліни «Арт-терапія» та «Психологічний практикум 3 групової психокорекції» 3 дітьми 3 обмеженими фізичними та психічними можливостями; б) 3 батьками дітей 3 обмеженими можливостями 3 метою надання психологічних консультацій та роботи в тренінгових групах, де $\epsilon$ простір психологічної безпеки, емпатії, толерантності, довіри, допомоги, підтримки, безумовного прийняття;

- збагачення навчальної діяльності технологіями, спрямованими на толерантне прийняття потреб та бажань дітей з особливими потребами.

До складників психологічної допомоги батькам дітей-інвалідів, що реалізуються в межах Центру включено: 1) можливість відвідування батьками лекційних та практичних занять дисциплін, що були перераховані раніше; 2) психологічну підтримку, психологічне розвантаження, що стає можливим завдяки відвідуванню ними лабораторних занять 3 арт-терапії, тренінгу спілкування та самопізнання. Такі заняття спрямовані на формування у батьків рефлексивних здібностей, на розвиток особистості в цілому, прийняття дитини-інваліда у власну картину світу, підвищення соціальної активності та укріплення адаптаційних механізмів особистості. На заняттях із арт-терапії та психологічного тренінгу батьки дитини-інваліда мають можливість звільнитися від негативних емоційних переживань, страхів, що контейнувалися та не мали можливості виходу назовні.

Основними перевагами групової форми взаємодії із батьками дітей-інвалідів є: 1) робота в групі сприяє подоланню відчуженості, ізольованості, відчуття одинокості та покинутості, адже у групі є люди зі схожими фізичними та психологічними проблемами і батьки починають відчувати прийняття, підтримку, формується впевненість у власних можливостях; руйнується міф про унікальність хвороби дитини; 2) набуття комунікативних навичок, навичок вираження емпатії, толерантності, підтримки, поваги до інших; 3) групова робота сприяє відреагуванню сильних емоцій: провини, агресії, сорому під час виконання вправ в безпечній соціально-психологічний атмосфері підтримки, терпимості та розуміння (на подолання психотравмуючих емоційних станів і переживань: образ, тривожності, відчуття самотності, провини, дратівливості, агресивності тощо в змісті психокорекції вказує С.Б. Кузікова [3]). Такі тренінгові заняття є більш схожими на групи зустрічей (за К. Рудестамом [4]) та спрямовані не на розв'язання проблеми, а на створення почуття спільності. Так, за умови сприятливої терапевтичної атмосфери тренінгова група може стати групою взаємодопомоги, адже, за умови відсутності критики та засудження, проте в атмосфері відкритості, обміну досвідом, знаннями, вільного вираження пережитими почуттями особистість змінює світогляд, трансформує відчай у бажання вирішення проблеми, підвищує компетентність у питаннях комунікацій, піклування, догляду, виховання дітей, що фасилітує механізм особистісної гармонізації. Особливістю тренінгових занять є початкова бесіда про емоції, почуття, переживання учасників, емоційний стан в цілому, що дає можливість психологу оцінити психологічний стан батьків дітей 3 особливими потребами та, за потреби, спрямувати їх до фахівця-психотерапевта або невропатолога.

Безперечною цінністю $є$ психологічна допомога для дитини-інваліда, адже порушення контактів у дитинстві призводить до створення проблеми соціуму у дорослому віці інвалідів. Унікальність даного Проекту полягає в системному підході до людини, що передбачає звернення до психолого-біологічних резервів особистості, механізмів особистісної компенсації та адаптації. Метою 
психологічної роботи з дітьми-інвалідами є відновлення соціального функціонування, налагодження особистісних відносин, розвиток комунікативних навичок, культури спілкування.

Важливим є використання засобів фізичної культури та спорту у реабілітації дітей-інвалідів, складовими яких $\epsilon$ : фізичні вправи у спортивному залі та в басейні. Фізичні вправи пов'язані із цілим рядом психічних процесів (увагою, пам'яттю, мовленням тощо), з мисленнєвою роботою, емоціями, переживаннями; вони розвивають інтереси, переконання, мотиви, потреби; формують волю, характер, поведінку та є одним із засобів духовного розвитку людини, тобто чинять вплив одночасно як на організм, так і на особистість. Заняття в басейні укріплюють здоров'я та загартовують організм. Для дітей-інвалідів спортивні ігри та інші види фізичної активності $є$ не лише емоційними за змістом, але й сприяють тренуванню організму та знижують частоту простудних захворювань. Дія води на організм сприяє укріпленню м'язів, покращує обмінні процеси, глибину дихання, поліпшують сон, апетит, настрій дитини. 3 дітьми взаємодіють студенти 1-4-го курсів бакалаврату та 1-2-го курсів магістратури денної форми навчання факультету «Здоров'я, фізичної культури та спорту» Міжнародного економіко-гуманітарного університету імені академіка Степана Дем'янчука.

Висновки 3 даного дослідження і перспективи подальших розвідок. У статті окреслено практичну парадигму підготовки психологів спеціальності 053 «Психологія» МЕГУ імені академіка Степана Дем'янчука завдяки реалізації проекту «На хвилях посмішок». Подальший науковий пошук вбачаємо в аналізі конкретних результатів реалізації вказаного Проекту.

Список використаних джерел

1. Індекс інклюзії: розвиток навчання та участі в життєдіяльності шкіл : посібник / [авт. тексту Тоні Бут] ; пер. з англ. - Київ : ТОВ Видавн. дім «Плеяди», 2015. - 190 с.

2. Колупаєва А. А. Діти з особливими потребами та організація їх навчання : наук.-метод. посіб. / А. А. Колупаєва, Л. О. Савчук. - вид. допов. та перероб. - Київ : Видавн. група «АТОПОЛ», 2011. $-274 \mathrm{c}$.

3. Кузікова С. В. Основи психокорекції : навч. посіб. / С. В. Кузькова. - Київ : Академвидав, 2012. - $320 \mathrm{c}$.

4. Рудестам К. Групповая психотерапия. Психокоррекционные группы: теория и практика / К. Рудестам ; [пер. с англ. : А. Голубев, Л. Трубицына, Э. Дикий ; общ. ред. и вступ. ст. Л. А. Петровской]. - Киев : PSYLIB, 2004. - 645 с.

5. Скрипник Т. Дитина з аутизмом в закладі освіти : метод. рек. / Т. Скрипник, Г. Супрун. Київ, 2015. - 16 с.

6. Теплов Б. М. Способности и одаренность / Б. М. Теплов // Психология индивидуальных различий. Тексты. - М. : Изд-во Моск. ун-та, 1982. - С. 133.

7. Технології психолого-педагогічного супроводу дітей з аутизмом в освітньому просторі : навч.-наоч. посіб. / [упоряд. Т. Скрипник]. - Київ : ТОВ Видавн. дім «Плеяди», 2015. - 56 с.

\section{References}

1. Indeks inklyuziyi: rozvytok navchannya ta uchasti v zhyttyediyal"nosti shkil : posibnuk / [avt. tekstu Toni But] ; per. z anhl. - Kyyiv : TOV Vydavn. dim «Pleyady», 2015. - $190 \mathrm{~s}$.

2. Kolupayeva A. A. Dity z osoblyvymy potrebamy ta orhanizaciya yix navchannya : nauk.-metod. posib. / A. A. Kolupayeva, L. O. Savchuk. - vyd. dopov. ta pererob. - Kyyiv : Vydavn. hrupa «ATOPOL», 2011. $-274 \mathrm{~s}$.

3. Kuzikova S. V. Osnovy psyxokorekciyi : navch. posib. / S. V. Kuzikova. - Kyyiv : Akademvydav, 2012. - $320 \mathrm{~s}$.

4. Rudestam K. Gruppovaja psihoterapija. Psihokorrekcionnye gruppy: teorija i praktika / K. Rudestam ; [per. s angl. : A. Golubev, L. Trubicyna, Je. Dikij ; obshh. red. i vstup. st. L. A. Petrovskoj]. Kiyev : PSYLIB, 2004. - $645 \mathrm{~s}$.

5. Skrypnyk T. Dytyna z autyzmom v zakladi osvity : metod. rek. / T. Skrypnyk, H. Suprun. Kyyiv, 2015. - $16 \mathrm{~s}$.

6. Teplov B. M. Sposobnosti i odarennost' / B. M. Teplov // Psihologija individual'nyh razlichij. Teksty. - M. : Izd-vo Mosk. un-ta, 1982. - S. 133.

7. Texnolohiyi psyxoloho-pedahohichnoho suprovodu ditej z autyzmom v osvitn"omu prostori : navch.-naoch. posib. / [uporyad. T. Skrypnyk]. - Kyyiv : TOV Vydavn. dim «Pleyady», 2015. - 56 s.

Yu. O. Michalchuk THE PRACTICAL TRAINING OF STUDENTS TO PSYCHOLOGICAL WORK WITH CHILDREN- DISABLED 
The article is devoted to the analysis of formation of personal and professional readiness of students of the specialty 053 "Psychology" for future psychological work with disabled children in rehabilitation centers and their psychological support in classes with inclusive education. It is noted that the formation of practical skills is possible only under the condition of direct interaction and communication that is possible at the International Economic and Humanitarian University named after Academician Stepan Demyanchuk due to the project "On the Waves of Smiles" based on the social partnership and aimed at involving students in a wide range of social interactions, expanding socio-cultural experience, forming tolerance as a personality quality, representing the integrative set of cognitive, emotional and behavioral components and is willing to construct the dialogue that is based on respect, empathy, acceptance. The author specifies the main goals, tasks, structure, principles of implementation and the directions of the project, describes the predicted results of changes for students-psychologists. The author describes the main directions of students' work with children with disabilities and their parents. The advantages of group form of psychological work for parents has been determined. Separately, the author focuses on the practical value of project implementation for students - future specialists in the field of psychology. The analysis of the results of the student survey of full-time education has been presented. The students responded to the question of willingness to work in the described project on a volunteer basis, highlighting the personal qualities that they can develop through the active participation in the project and the qualities that will help to work with disabled children.

Key words: disabled child, subject-subject interaction, professional-personal development, professional activity, humanism, tolerance, psychotrauma, psychotrainig technologies. 